\title{
METODOLOGIAS VISUAIS NA EDUCAÇÃO EM DIREITOS HUMANOS COM ESTUDANTES MIGRANTES NA UFPR
}

\author{
Visual methodologies in human rights education with migrant students at \\ the Federal University of Paraná
}

Tatyana Scheila FRIEDRICH

Universidade Federal do Paraná

tatyanafriedrich@yahoo.com.br

https://orcid.org/0000-0002-9786-7959

Jaqueline BERTOLDO

Universidade Federal do Paraná

bertoldojaque@gmail.com

https://orcid.org/0000-0002-3090-3417

RESUMO: O presente estudo tem como objetivo refletir sobre a utilização dos métodos visuais no contexto de educação em direitos humanos com públicos plurilíngues, além de discutir as diferentes percepções de estudantes migrantes acerca das dinâmicas entre migração, direitos humanos, justiça e realidade social. Trata-se de um estudo de caso a partir da experiência da disciplina "Migração, Refúgio e Direitos Humanos" na Universidade Federal do Paraná. A disciplina integra o Programa de Formação Suplementar: Ciclo de Acolhimento Acadêmico para Estudantes Refugiados, destinado aos estudantes migrantes e refugiados ingressantes nos cursos de graduação da instituição por meio de políticas específicas para esse público. A utilização das metodologias visuais possibilitou identificar e refletir sobre as diferentes percepções e compreensões dos estudantes acerca dos direitos humanos, em que a diversidade sociocultural e linguística se revelou como um fator positivo e determinante para os debates e construção de sentidos comuns. PALAVRAS-CHAVE: Métodos visuais; Refúgio; Educação em direitos humanos.

ABSTRACT: This study aims to reflect on the use of visual methods in a context of human rights education with plurilingual audiences, in addition to discussing the different perceptions of migrant students on the dynamics between migration, human rights, justice and social reality. It is a case study based on the experience of the discipline "Migration, Refuge and Human Rights" of the Federal University of Paraná.

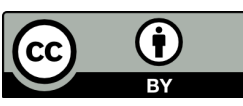


The subject is part of the Supplementary Training Program: Academic Reception Cycle for Refugee Students, aimed at migrant students and refugees entering the institution's undergraduate courses through specific policies for this public. Through the use of visual methodologies, it was possible to perceive and reflect on the different perceptions and understandings of students about human rights, in which socio-cultural and linguistic diversity proved to be a positive and determining factor for debates and the construction of common meanings. KEY-WORDS: Visual methodologies; Refugee; Human Rights Education.

\section{INTRODUÇÃO}

O uso de metodologias visuais em contextos educacionais plurilinguísticos, apesar de crescente no campo das ciências sociais e humanas, ainda não encontra espaço nos estudos do direito e da educação jurídica em geral. Por outro lado, a realidade do acesso à educação superior para migrantes e refugiados no Brasil têm apresentado diversos desafios ao campo pedagógico e também jurídico, especialmente em razão da falta de políticas públicas adequadas para garantir direitos linguísticos e culturais também no espaço educacional. Além disso, a inter-relação entre direito e educação é cada vez mais importante, tendo em vista que o direito à educação possui um papel fundamental no acesso aos demais direitos humanos, especialmente no caso de populações mais vulneráveis, conforme já afirmado em diversos documentos internacionais.

Assim, a experimentação de metodologias diferenciadas no contexto da educação em direitos humanos apresenta novas e outras possibilidades de co-interpretação e coconstrução de sentidos sobre aquilo que envolve o jurídico e os direitos no contexto das migrações e do refúgio no Brasil. A utilização das metodologias visuais permite reconfigurar o ambiente educacional de discussão sobre os direitos humanos, com uma especial atenção à diversidade cultural e linguística dos sujeitos envolvidos.

Diante desse contexto, o objetivo do estudo, além de discutir sobre as possibilidades de utilização das metodologias visuais no processo de educação em direitos humanos, consiste em refletir sobre as diferentes percepções de estudantes migrantes acerca das dinâmicas entre migração, direitos humanos, justiça e realidade social. Trata-se de um estudo de caso de abordagem qualitativa, cuja análise será feita com base nos resultados de atividades aplicadas com os alunos na disciplina "Migração, Refúgio e Direitos Humanos" que integra as atividades do Ciclo de Acolhimento Acadêmico para Estudantes Refugiados (PSF-Refugiados) da UFRP. No âmbito deste artigo apresentamos resultados 
parciais do estudo e que compreendem um recorte diante das atividades e momentos da disciplina mencionada, o que não impede abordagens futuras. Além disso, ressaltamos que todo o processo de pesquisa observa as dimensões da ética e da proteção de seres humanos, bem como busca resguardar as identidades de todos os estudantes.

Em um primeiro momento, apresentamos o contexto da pesquisa sobre a política de ingresso de migrantes e refugiados na Universidade Federal do Paraná e o Programa de Formação Suplementar, no qual está inserida a disciplina "Migração, Refúgio e Direitos Humanos". Posteriormente, refletimos sobre a possibilidade do uso das metodologias visuais na educação em direitos humanos com públicos plurilíngues na universidade (seção 1). A partir de desenhos e outros recursos visuais utilizados, problematizamos as diferentes percepções e compreensões sobre o jurídico e o social no contexto da educação em direitos humanos (seção 2).

\section{DA POSSIBILIDADE DE UTILIZAÇÃO DOS MÉTODOS VISUAIS NA EDU- CAÇÃO EM DIREITOS HUMANOS}

A realidade das migrações internacionais contemporâneas para o Brasil tem provocado transformações e diversos desafios no âmbito da proteção jurídica, como o direito à educação em todos os níveis de ensino. A importância do acesso aos direitos pela população migrante no país tem como marco a aprovação da Lei de Migração em 2017 que, além de substituir o antigo Estatuto do Estrangeiro, passou a prever taxativamente direitos civis, sociais, culturais e econômicos aos migrantes em território nacional e, independente de condição migratória, inclusive o direito à educação pública. Nesse contexto, o papel das universidades públicas e privadas, em suas ações de ensino, pesquisa e extensão, e em parceria com a Agência da ONU para Refugiados (ACNUR) por meio da Cátedra Sérgio Vieira de Mello, tem sido fundamental na criação de políticas públicas de ação afirmativa para facilitar o acesso ao ensino superior por refugiados e migrantes internacionais, gerando novas e outras formas de integração social e econômica.

No caso da Universidade Federal do Paraná, desde 2013, o Programa de Extensão Política Migratória e Universidade Brasileira atua no acolhimento e apoio à população migrante e refugiada no estado do Paraná. Diante das múltiplas vulnerabilidades vivenciadas pela população migrante no Brasil, o programa conta com a participação de professores e estudantes de diferentes áreas de atuação: direito (assessoria jurídica); letras (ensino de português); ciências da computação (aulas de informática); psicologia (acompanhamento psicológico); além dos cursos de sociologia e história. Por meio das atividades do programa, foi possível identificar uma grande demanda por parte da 
comunidade migrante para reinserção universitária e/ou acesso ao ensino superior, o que possibilitou, ainda em 2014, o ingresso da primeira estudante refugiada na instituição.

Assim, em 2014 foi aprovada a Resolução 13/14, que prevê as normas para o acesso de migrantes e portadores do estado de refugiado ou de visto humanitário e que "tenham iniciado cursos superiores em instituições de ensino no estrangeiro" aos cursos de graduação da UFPR, conhecido como Programa Reingresso (UFPR, 2014). Segundo Ruano e Lopes (2019, p. 93), o Programa é destinado ao aproveitamento de vagas remanescentes da instituição, com o objetivo de contribuir com a reinserção de migrantes e refugiados que tiveram seus estudos interrompidos em razão da migração.

Já em novembro de 2018, foi aprovada uma nova resolução para criação de vagas suplementares e processo seletivo específico e exclusivo para ingresso de migrantes com visto humanitário ou portadores da condição de refugiados. Segundo a Resolução n ${ }^{\circ} 63 / 18$, cada curso deverá disponibilizar uma vaga suplementar, "a ser preenchida por escolha dos candidatos na ordem de classificação no Processo Seletivo, até o limite de 10 vagas em cada ano" (UFPR, 2018). Dessa forma, atualmente, a UFPR conta com duas modalidades de acesso ao ensino superior pela população migrante e refugiada: o reingresso, no caso daquelas pessoas que interromperam cursos de graduação no exterior e o vestibular exclusivo para aqueles que buscam ingressar em um curso de graduação no Brasil.

Nesse contexto, a Agência da ONU para Refugiados (ACNUR) tem acompanhado os processos de ingresso de refugiados nas instituições de ensino superior por meio da implementação da Cátedra Sérgio Vieira de Mello em 14 universidades conveniadas que contam com procedimentos facilitados. Conforme o Relatório Anual de 2020, a UFPR contabiliza 115 estudantes regularmente matriculados nos seus cursos de graduação na condição de migrantes com visto humanitário ou refugiados (CSVM, 2020). Além de promover a ampliação do acesso à educação superior, tais políticas representam o compromisso das instituições na "busca de superação das desigualdades e no combate a todas as formas de discriminação" (UFPR, 2018).

Sobre os dados e perfil desses estudantes, Ruano (2019, p. 144) destaca que, entre os anos de 2014 e 2018, 52 migrantes e refugiados foram matriculados na UFPR, sendo a maioria destes (36) de nacionalidade haitiana, tendo em vista o grande fluxo migratório do Haiti para o Brasil no período. Nesse período, todavia, constatou-se uma grande diversidade, com estudantes da Síria, Benin, Congo, Guiné-Bissau, Peru, República Democrática do Congo e Venezuela. Importante ressaltar que o aumento expressivo do fluxo migratório de venezuelanos para o Brasil nos últimos anos impactou também as políticas públicas com grande demanda e procura por essa população. Assim, no cenário 
da presente pesquisa com os estudantes ingressantes no ano de 2020, destaca-se a presença de estudantes do Haiti e da Venezuela, refletindo a realidade dos próprios fluxos migratórios para o país.

Com relação aos cursos, a autora destaca que o Programa Reingresso se faz presente nas mais diversas áreas de ensino, sendo que à época a maioria dos estudantes estava matriculada nos cursos de Engenharia Civil, Agronomia, Biomedicina e Ciências Biológicas. Registrou-se também estudantes nos cursos de Administração, Ciências da Computação, Direito, Letras e Odontologia (RUANO, 2019, p. 145). A pesquisa de Ruano (2019, p. 146) também destacou a diferença de gênero e identificou que o número de ingressantes é majoritariamente masculino, apesar de que "a quantidade de mulheres vem crescendo consideravelmente nos últimos três anos".

Diante da diversidade e dos desafios no acolhimento desses estudantes, desde 2016, a UFPR passou a oferecer o Curso de Acolhimento Linguístico e Acadêmico que conta com aulas de português acadêmico e apresentação dos serviços e estrutura da universidade, incluindo visitas guiadas e orientações sobre os serviços oferecidos pela instituição. Em continuidade a esse processo, no ano de 2019, foi aprovado o Programa de Formação Suplementar: Ciclo de Acolhimento Acadêmico para Estudantes Refugiados (PSF-Refugiados) que criou o chamado Ano 0, ou seja, um ano letivo diferenciado direcionado aos estudantes migrantes e refugiados para proporcionar "adaptação, acolhimento, integração e inserção do estudante migrante à vida universitária e social do país" (UFPR, 2019a). Segundo a UFPR, uma das ações do programa é inserir na grade curricular logo no início do curso de graduação aulas de língua portuguesa voltadas à vida acadêmica, de informática e de direito brasileiro (UFPR, 2020).

Dentre as atividades incluídas no programa de formação suplementar está a participação desses estudantes na disciplina "Migração, Refúgio e Direitos Humanos", vinculada ao Setor de Ciências Jurídicas da UFPR, que tem como objetivo o estudo de temas de direito, direito da migração, do refúgio e dos direitos humanos em geral. A disciplina integra os objetivos descritos na Resolução 059/19 que instituiu o PSFRefugiados e, no art. $2^{\circ}$, prevê a realização de atividades formativas que contemplem o desenvolvimento de competências mínimas, com destaque ao inciso II:

[...]II- compreender a sua inserção na sociedade brasileira como um sujeito de direitos e deveres, em plenas condições de desenvolver-se no plano pessoal e profissional e contribuir com o seu conhecimento e trabalho para a construção de relações sociais mais equitativas e democráticas (UFPR, 2019b). 
A inserção da disciplina na grade curricular da graduação para estudantes refugiados e migrantes com visto humanitário também estava apoiada na compreensão de educação em direitos humanos que consiste em um "processo sistemático e multidimensional" na formação do sujeito de direito, na criação de uma cultura de direitos humanos e de promoção de valores de tolerância, solidariedade e valorização das diversidades (BRASIL, 2018, p. 11). A educação, afirmada como direito humano em diversos instrumentos internacionais e nacionais ${ }^{1}$, possui um papel fundamental no acesso a outros direitos, especialmente dos grupos sociais mais vulneráveis, como migrantes e refugiados. Contudo, como falar em direitos humanos de migrantes e refugiados se estes consistem em direitos afirmados em uma língua que não é a sua e que, em muitos casos, não compreendem? Acesso a direitos humanos pressupõe, primeiramente, conhecê-los, apropriar-se deles, afinal, ninguém reivindica um direito se não sabe que o possui, se não o percebe dentro da sua própria realidade cultural e linguística. Por isso, para além de conhecer sobre as regras e estruturas de funcionamento da sociedade brasileira por meio da organização das leis, normas e da Constituição Federal, trata-se de perceber o direito e os direitos humanos como instrumentos de emancipação e proteção contra toda e qualquer forma de exploração e violação.

Ofertada pela primeira vez no primeiro semestre de 2020, sob coordenação da Prof. ${ }^{a}$ Dr. ${ }^{a}$ Tatyana Friedrich, as atividades da disciplina foram iniciadas de forma presencial e, em razão da pandemia de coronavírus, passaram para a modalidade de ensino remoto emergencial (ERE). Além disso, foi ofertada como disciplina optativa aos demais alunos da faculdade de direito da universidade, o que resultou em um espaço de ensino e aprendizagem cultural e linguisticamente muito diverso. Diante dessa realidade, dentre os procedimentos didáticos foi prevista a utilização de metodologias visuais, como fotografias, desenhos, colagens, figuras e outros recursos que ultrapassem o papel da língua ao acessar o sujeito e suas representações sobre o jurídico e os direitos humanos. Isso porque, conforme explica Brandão (2017), os desenhos e outros gêneros visuais são compreendidos como narrativas que permitem aos participantes atribuírem sentido às suas próprias experiências.

Imagens constituem representações importantes em nossas vidas, sejam elas placas para nos guiar por uma estrada, fotos para registrarmos

\footnotetext{
${ }^{1}$ Entre os principais documentos internacionais estão a Declaração Universal dos Direitos Humanos de 1948, o Pacto Internacional sobre os direitos econômicos, sociais e culturais de 1960 e a própria Convenção Relativa ao Estatuto dos Refugiados de 1951. Além disso, no âmbito nacional, destacamos a Constituição Federal e a Lei de Diretrizes e Bases da Educação Nacional, além da Lei de Migração e o Estatuto dos Refugiados.
} 
momentos, ou obras de arte para apreciarmos as narrativas culturais, sociais e históricas que as permeiam. Imagens "interpretam o mundo; exibindo-o de maneiras bem peculiares; elas o representam" (Rose, 2012, p. 2). Sobretudo, imagens comunicam experiências (Bach, 2007; Riessman, 2008) (BRANDÃO, 2017).

Sendo um campo empiricamente ainda pouco explorado, o uso das metodologias visuais permite uma ampla diversidade de abordagens de pesquisa, com diferentes públicos e metodologias aplicadas. Chik e Melo-Pfeifer (2020, p. 2) explicam que o "visual" pode se referir a diferentes formatos de dados, como fotografias, desenhos, vídeos e até textos digitais multimodais. Além disso, as autoras destacam que essas fontes podem ser utilizadas de forma independente ou de maneira complementar a outras metodologias (CHIK e MELO-PFEIFER, 2020, p. 2) e, "se não forem reduzidas a uma técnica ou a instrumentos (de investigação, de ensino), inscrevem-se, como efeito e em pleno direito, numa orientação diversitária" que prioriza o que os participantes têm a expressar (MOORE, 2017, p. 13). Considerando a complexidade da educação em direitos humanos com públicos migrantes no contexto brasileiro, uma abordagem plural e inovadora das práticas pedagógicas e investigativas parece mais promissora para compreender com maior profundidade a relação dos sujeitos com os diferentes campos político-normativo em que estão inseridos.

Conforme explicam Melo-Pfeifer e Simões (2017, p. 17), os métodos visuais adquiriram importância nas investigações em ciências sociais e humanas ao renovar a paisagem metodológica dos estudos empíricos em uma "tentativa de acesso ao sujeito na sua integralidade e na sua complexidade, por vezes, difícil de descrever, de se escrever e de se representar verbalmente" (MELO-PFEIFER e SIMÕES, 2017, p. 18). A utilização dos métodos visuais, segundo Moore (2017), permite a crianças e adultos expressarem sua própria visão de mundo, "levando a sério" o que pensam e o que têm a dizer. Apesar de a autora referir-se ao universo do ensino e aprendizagem de línguas, entendemos que o uso de tais metodologias também permite ao sujeito a possibilidade de "co-construir e cointerpretar" (MOORE, 2017, p. 13) o que é o jurídico e os direitos humanos em sua relação com o país de origem e o de acolhida, nas diferentes culturas e línguas em que está inserido.

Reafirmando Moore (2017, p. 13-14), são metodologias que promovem responsabilidade social, pois se inscrevem em um modelo que coloca a "pluralidade, a heterogeneidade e a alteridade" no centro do processo educativo e de investigação, além de tornar a reflexividade um princípio da formação para "cada ator envolvido na ação de ensinar e de aprender". Diante da diversidade cultural e linguística dos espaços educacionais atuais, a utilização de abordagens plurais como o uso de metodologias Revista X, v. 16, n. 2, p. 461-484, 2021. 
visuais permite "a criação de atitudes positivas e de respeito face à língua e cultura do Outro" (COELHO e SIMÕES, 2017).

Além disso, também concordamos com Simões (2017) que só haverá uma verdadeira educação para o plurilinguismo e o contato intercultural se forem valorizadas as representações do indivíduo face ao outro e às diferentes línguas. Da mesma forma, a educação em direitos humanos e a possibilidade de construção de um sujeito consciente dos seus direitos e inserido na construção de uma cultura de respeito e tolerância à dignidade humana, somente serão possíveis por meio de abordagens educativas plurais e que valorizem a experiência do outro.

Nesse sentido, Candau (2008, p. 291) destaca que o processo de educação em direitos humanos não pode ser dissociado das estratégias metodológicas e pedagógicas envolvidas que também devem estar em consonância com uma visão contextualizada e histórico-crítica da importância e do papel dos direitos humanos na nossa sociedade. A crítica da autora vai ao sentido de que constantemente as práticas pedagógicas, mesmo na educação em direitos humanos, são reduzidas a exposições verbais, unilaterais e sem espaço para as experiências e percepções dos próprios estudantes. O ensino-aprendizagem em direitos humanos, para além de simples transmissão de conhecimentos sobre direitos, consiste em um processo de construção coletiva, possível somente a partir da diversidade de sujeitos envolvidos e das metodologias aplicadas. Por isso, a possibilidade de utilização das metodologias visuais nesse contexto está orientada em uma concepção onde os sujeitos possam expressar de diferentes formas as suas percepções e a sua relação com os direitos humanos, para além da supremacia da linguagem escrita.

Na próxima seção, apresentamos alguns resultados preliminares acerca do uso de metodologias visuais no contexto da educação em direitos humanos com estudantes universitários migrantes da Universidade Federal do Paraná, especialmente por meio da utilização de desenhos e figuras como narrativas visuais e da mediação das percepções dos estudantes envolvidos.

\section{DESENHANDO DIREITOS E (IN)JUSTIÇAS: PERCEPÇÕES DE ESTU- DANTES MIGRANTES E REFUGIADOS}

Diante do crescimento da mobilidade humana internacional, no caso de pessoas em situação de refúgio e não refugiadas, os sistemas educacionais são cada vez mais desafiados em saber lidar com as múltiplas diversidades dos estudantes, sejam elas linguísticas, culturais, econômicas e sociais. Nesse contexto, as discussões e práticas para uma educação intercultural orientada pelos direitos humanos passam, necessariamente, Revista X, v. 16, n. 2, p. 461-484, 2021. 
pelo questionamento das metodologias de ensino e/ou investigação. Por isso, nessa pesquisa, apresentamos como centralidade da prática pedagógica em direitos humanos e do processo de investigação, os desenhos elaborados por estudantes universitários migrantes da UFPR.

Conforme explica Simões (2017, p. 86), desde a primeira metade do século XX, o desenho tem sido utilizado como forma de acessar as representações dos sujeitos sobre o mundo nas áreas da sociologia, antropologia e psicologia. Por meio do desenho, o sujeito, ao projetar-se no irreal ou imaginário sem julgamento externo, pode representar o seu universo de referência e de percepção sobre as relações sociais onde está inserido (SIMÕES, 2017, 87). Além disso, Moore (2017, p. 13) destaca, no contexto da aprendizagem de línguas, que o desenho estimula a reflexão, a construção cognitiva e a interação por meio de uma encenação diferente do que é permitido pela palavra e permite aos participantes um envolvimento mais criativo nas suas aprendizagens e relações.

Nesse mesmo sentido, Melo-Pfeifer e Ferreira (2017) explicam que o desenho tem um potencial em afirmar-se como narrativa, tendo em vista que permite materializar categorias como tempo, espaço, ações e personagens. O uso dos gêneros visuais apresenta novas possibilidades aos estudos sobre narrativas, pois o que "pode ser expressado visualmente, nem sempre pode ser comunicado verbalmente" (BRANDÃO, 2017). Embora a análise da narrativa visual possa ser feita por meio dos elementos semióticos em si, contudo, a "verbalização do seu significado é sempre uma des/reconstrução desse sentido, dado que decorre da interferência, voluntária ou não, de um interlocutor (presente ou ausente) e da mediação da linguagem" (MELO-PFEIFER e FERREIRA, 2017). Deste modo, destacamos que a complexidade dos métodos aplicados e dos objetos de análise pressupõe, conforme afirmam Melo-Pfeifer e Ferreira (2017, p. 130), a necessidade de perspectivas transdisciplinares e que levam a opção pelo uso das narrativas visuais.

A opção pela elaboração de desenhos como tarefa dirigida aos estudantes de graduação se deu, especialmente, em razão do contexto em que estava programada a disciplina "Migração, Refúgio e Direitos Humanos": além da presença de estudantes não migrantes, o universo de estudantes migrantes e refugiados compreende diferentes nacionalidades, países de origem, cursos de graduação e realidades sócio-linguísticas. Assim, entendemos que a utilização dos desenhos consiste em uma forma eficaz não só de acessar os sujeitos e suas percepções, mas, principalmente, na possibilidade co-criar um espaço de compreensões comuns sobre os direitos humanos. Nesse sentido, as imagens foram utilizadas em um duplo sentido: como metodologia de recolha de dados e como metodologia de ensino no âmbito da disciplina. 
A primeira atividade proposta aos estudantes aconteceu no primeiro dia de aula da disciplina, após a apresentação dos objetivos e das metodologias que seriam utilizadas durante o semestre, bem como da apresentação pessoal de cada um dos(as) participantes. Após a elaboração dos desenhos, os estudantes foram convidados a relatar sobre as imagens. Com o objetivo de iniciar as discussões e reflexões sobre o que é o direito e, tendo em vista a diversidade de estudantes de diferentes cursos de graduação, optou-se por debater as diferentes noções e realidades sobre a justiça, tanto no Brasil e, principalmente, como cada estudante migrante ou refugiado entende a justiça no seu país e nas suas realidades. Ao abordar a noção de justiça, foi possível discutir e refletir sobre as dinâmicas entre migração, direitos humanos e os diferentes contextos sociais em que estão inseridos os estudantes. A reflexão parte da análise dos desenhos de 10 estudantes, elaborados durante o período de aula presencial, no mês de março de 2020, que antecedeu o início da pandemia de coronavírus no Brasil. Os nomes dos estudantes foram retirados, atendendo aos preceitos da ética em pesquisa como forma de proteger suas identidades e trajetórias.

\section{Apresentação dos resultados}

Na sequência, no desenho do estudante haitiano aparece uma cisão entre a "justiça para pobre", representada por uma pessoa aparentemente com olhos pequenos ou vendados, e a "justiça para ricos", que aparece representada por alguém de olhos bem grandes ou abertos. O estudante remete à ideia de que a justiça confere tratamentos diferenciados aos sujeitos, contrariando o princípio da igualdade de direitos e deveres presente tanto na Constituição do Haiti como na Constituição Brasileira, inseridas na concepção liberal que orientou as concepções modernas de justiça. Segundo o art. 18 da Constituição Haitiana de 1987, “os haitianos devem ser iguais perante a lei”, além de apresentar o lema nacional no art. $4^{\circ}$, qual seja: liberdade, igualdade e fraternidade (HAITI, 1987). Já a Constituição Brasileira destaca, no art. 5, que "todos são iguais perante a lei, sem distinção de qualquer natureza". Por outro lado, ao remeter a noção de "pobreza" e "riqueza" em sua ideia sobre a justiça, pode-se afirmar que o desenho também faz relação entre a justiça e a manutenção (ou não) das desigualdades sociais. Diante da concepção apresentada pelo estudante nessa imagem, foi possível então discutir e refletir sobre as noções de igualdade e equidade diante do contexto de desigualdades sociais e econômicas na realidade brasileira e haitiana. 


\section{Imagem 1:}

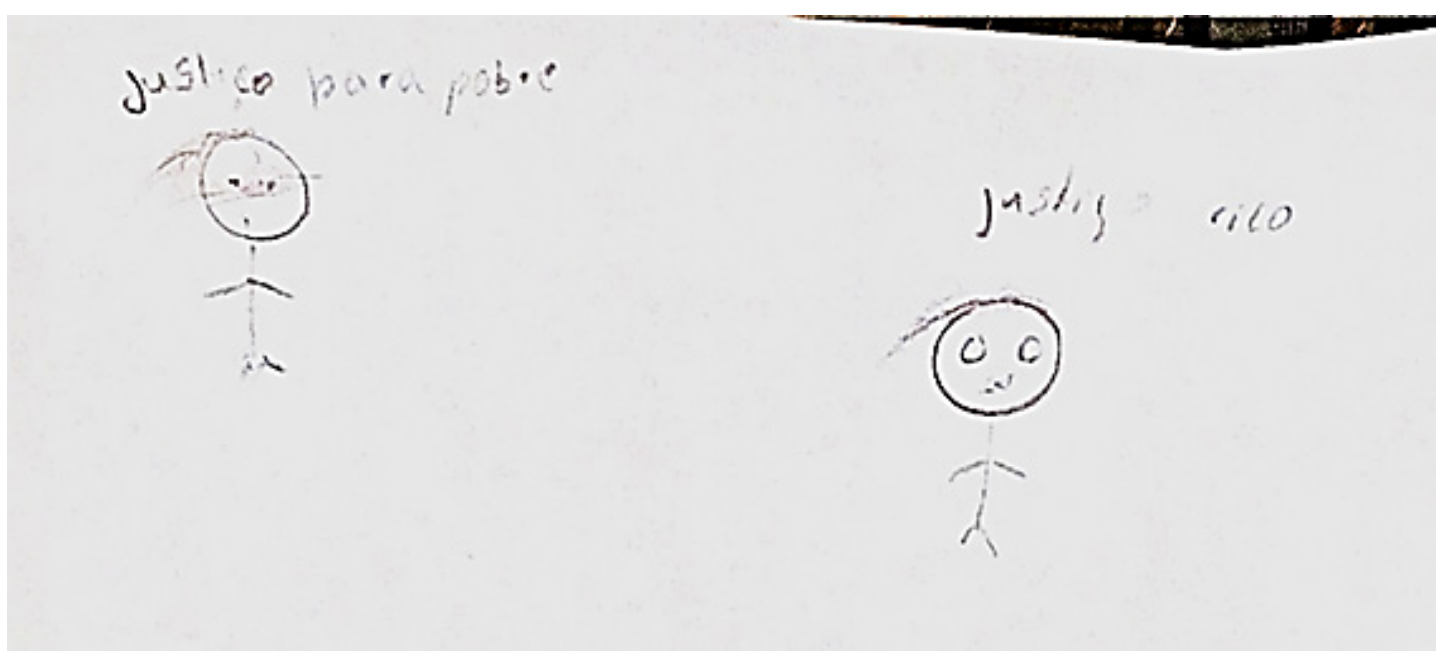

Fonte: as autoras (2020).

\#PraCegoVer: Desenho na cor preta. Canto superior esquerdo a expressão "justiça para pobre", abaixo uma pessoa com os olhos pequenos e vendados. Lado direito a expressão "justiça rico", abaixo uma pessoa com os olhos bem grandes e abertos.

Já o segundo desenho apresentado, também de um estudante haitiano, faz referência a uma balança, um símbolo tradicionalmente atribuído à ideia de justiça. Conforme Leite e Dias (2013), em uma pesquisa sobre as representações de justiça a partir da imagem da balança, explica que essas normalmente "possuem braços iguais, pesos em proporção, o que as torna alinhadas, numa significação relacional entre castigo e culpa que, equiparados, apontam para a harmonia, equivalência e equilíbrio". No desenho, fica dúvida sobre ela estar ou não em equilíbrio e se os pesos são ou não iguais, além de aparecer com um novo componente, sendo carregada ou transportada por uma camionete que, segundo o estudante significa que a justiça está sempre em movimento. Além disso, a utilização da balança associada à justiça remete a uma ideia de medidas, pesos e contrapesos, equilíbrio e desequilíbrio, sejam entre sujeitos, instituições, normas, valores que compreendem o universo jurídico. 


\section{Imagem 2:}

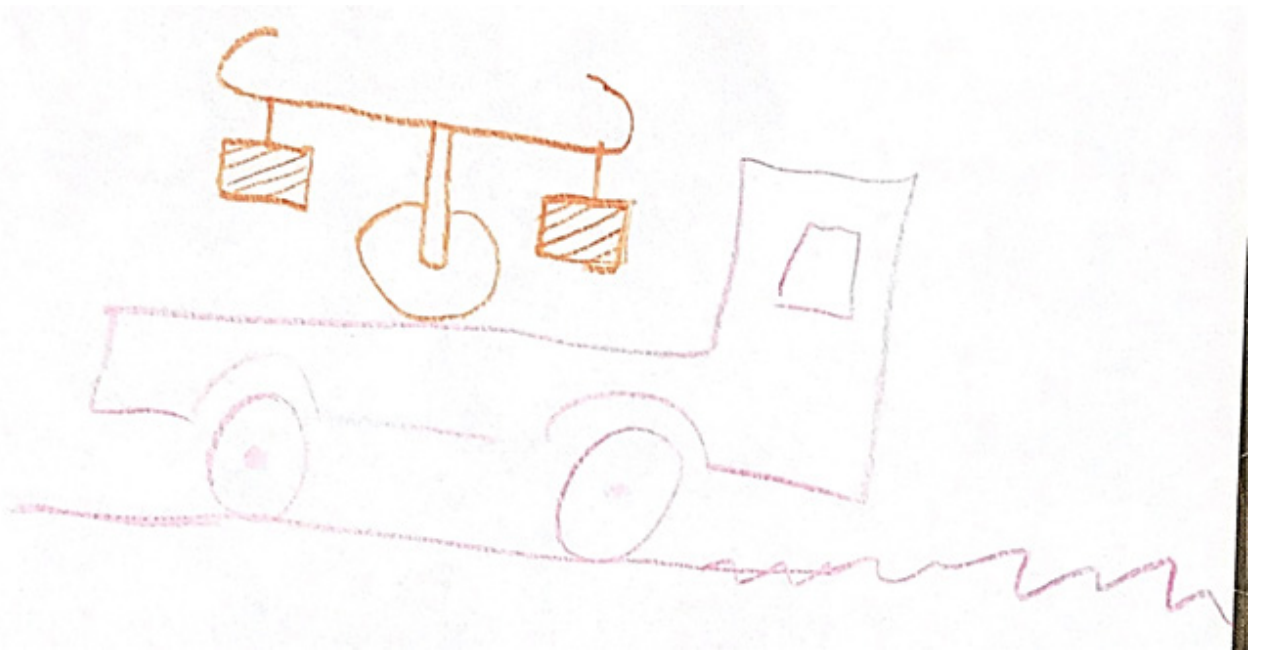

Fonte: as autoras (2020).

\#PraCegoVer: Desenho nas cores laranja e roxo. Vista lateral de uma camionete descendo por uma rua, a camionete e a rua estão na cor roxa, na carroceria uma grande balança de cor laranja.

Na sequência, outro estudante destaca a balança como representação da justiça, todavia, nesse caso, há dois polos bem delimitados, em que um deles é ocupado por alguma autoridade e o outro por várias pessoas, não identificadas. Segundo Leite e Dias (2013, p. 13), quando as balanças estão representadas de forma desigual entende-se "que as imagens apresentam elementos indicativos de descrédito" e poderiam também no nosso caso, significar uma "certa incredulidade operacional na justiça institucionalizada". Contudo, localizado ao lado esquerdo da balança, o estudante escreveu "opção pelo povo", dentro de outro desenho que remete a uma casa/construção com três portas. Apesar de não ser possível determinar de qual autoridade o desenho trata, esta está definida pela roupa, o cinto e um chapéu. Em contrapartida, as demais pessoas que, possivelmente, se correspondem ao "povo", foram apresentadas de forma genérica e abstrata. Nesse caso, a balança pende visivelmente para o grupo denominado "povo" e a justiça seria, então, a opção pelo povo. Além disso, o estudante ressaltou que somente por meio da organização popular há possibilidade de transformação dessa realidade. 


\section{Imagem 3:}

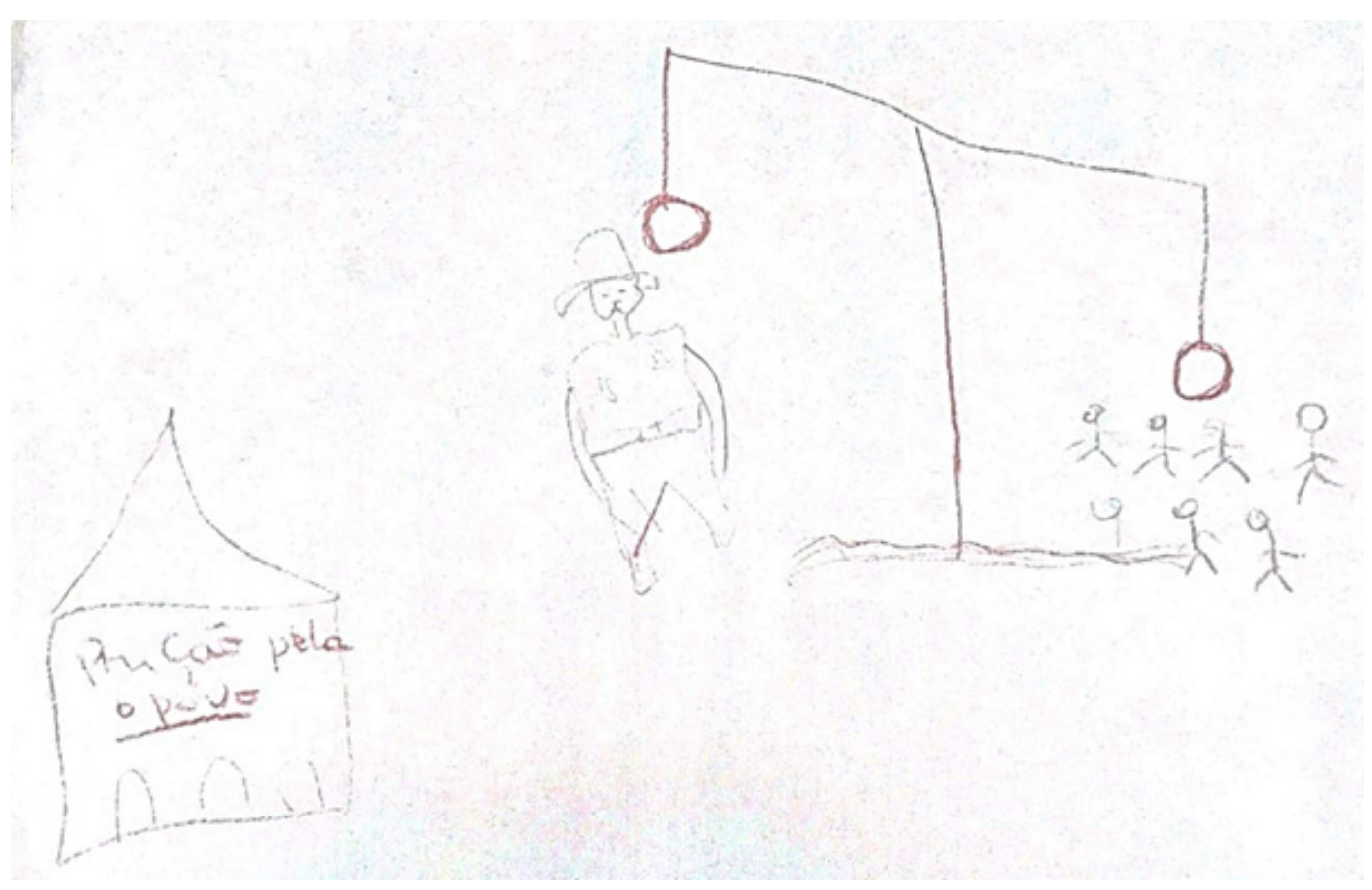

Fonte: as autoras (2020).

\#PraCegoVer: Desenho na cor preta. Lado direito superior uma balança gigante pendendo para à direita onde estão desenhadas sete pessoas. Do lado esquerdo uma pessoa/autoridade quase do tamanho da balança, usa chapéu, uniforme e cinto. Lado esquerdo mais abaixo, uma construção com três portas e a escrita “opção pelo povo".

O desenho seguinte também apresenta a figura da balança em uma referência à justiça e o desequilíbrio entre diferentes forças e realidades. Nesse caso, a balança está sendo segurada por uma pessoa, uma possível personificação da justiça, e que dispõe do poder de decidir sobre quem serão os privilegiados da justiça. Segundo o relato do estudante, as poucas pessoas no canto direito e que ocupam um pequeno espaço do desenho, representam aqueles que são privilegiados, que têm fácil acesso aos direitos, bens e serviços, enquanto do outro lado há um número muito grande de pessoas sem acesso ao básico. Em sua perspectiva, enquanto poucas pessoas vivem em uma condição de privilégio, a grande maioria continua com os direitos básicos sendo negados, o que simboliza uma justiça desigual e em desequilíbrio. Além disso, o desenho apresenta uma figura da justiça com um olho bem aberto, direcionado às massas, em contraposição a uma justiça de olhos fechados e que não enxerga os privilégios de alguns poucos indivíduos. Ao contrário da imagem tradicional da justiça cega e, supostamente imparcial, retrata uma justiça parcial e fragmentada, que escolhe o que enxergar e o que ocultar. 


\section{Imagem 4:}

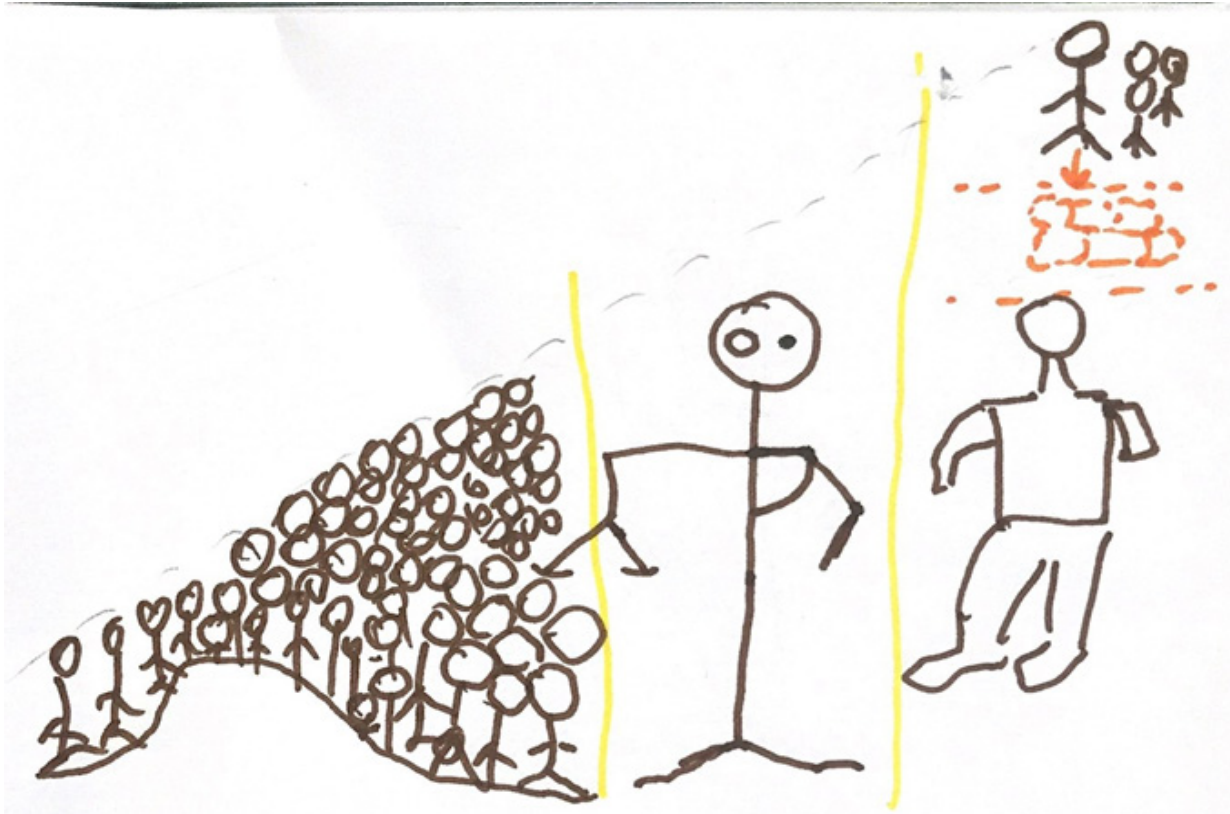

Fonte: as autoras (2020).

\#PraCegoVer: Desenho na cor marrom, divido em três partes, da esquerda para a direita. Primeira parte um amontoado de pessoas e a separação com uma linha vertical amarela. Sobre a linha uma balança que está na mão de uma pessoa gigante que ocupa a segunda parte, um de seus olhos está bem arregalado. Na terceira parte uma pessoa maior de costas, ela observa outras três pessoas, delas sai uma seta indicando retângulos e linhas tracejadas em laranja.

Outros dois desenhos, de duas estudantes venezuelanas, apresentaram percepções de evidente descontentamento sobre a realidade da justiça no seu país, especialmente em razão do difícil acesso, morosidade do sistema judiciário e altos custos. Após a discussão com a turma, ficou evidente a insatisfação diante do sistema político, da corrupção e da falta de direitos básicos para a população. Na primeira imagem, a estudante utilizou um desenho de cunho pejorativo, pois, segundo ela, a situação da Venezuela é bastante problemática e parece não haver possibilidade de mudanças nesse sentido. A imagem de um rosto sorrindo no interior da figura, bem como a fala da estudante, denota uma postura de incredulidade diante da realidade, em que não há alternativa senão denunciar, mesmo em formato de piada e brincadeira. No caso destas estudantes, os desenhos, acompanhados das falas, representam a atual situação de crise vivenciada pelo país e que levou aos grandes fluxos migratórios de venezuelanos que deixaram a Venezuela, sendo o Brasil um dos principais países de acolhida. Segundo o relatório Tendências Globais, no Revista X, v. 16, n. 2, p. 461-484, 2021. 
final de 2019, havia cerca de 4,5 milhões de venezuelanos deslocados, sendo considerado o "maior êxodo na história recente da região e uma das maiores crises de deslocamento do mundo" (ACNUR, 2019).

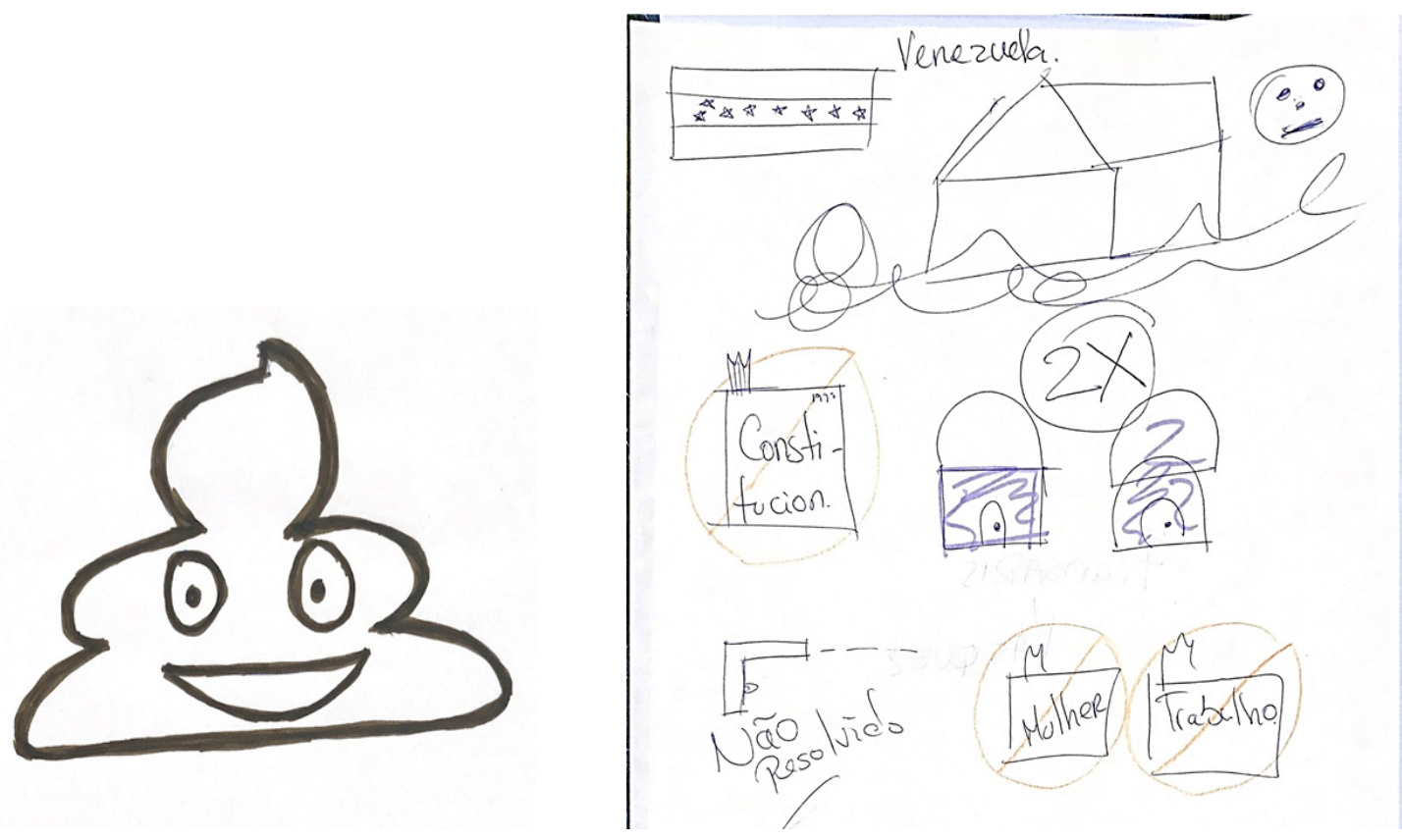

\section{Imagens 5 e 6:}

Fonte: as autoras (2020).

\#PraCegoVer: Dois desenhos na cor preta. O primeiro, à esquerda o emoji de um cocô sorrindo. O segundo, canto superior esquerdo uma bandeira e o nome Venezuela, abaixo uma casa e uma carinha triste ao lado. Embaixo da casa há três desenhos: um livro com a palavra constituição e sobre ele um círculo cortado ao meio por uma linha na diagonal. Ao lado duas casas com a expressão 2 X. Abaixo mais três desenhos: uma arma com a expressão "não resolvido" e ao lado o desenho de dois livros com os títulos mulher e trabalho. Sobre ambos o círculo cortado ao meio por uma linha na diagonal.

No segundo desenho, a representação de uma constituição dentro de um círculo entrecortado remete a ideia de suspensão de uma determinada ordem constitucional, política ou de direitos, em alusão à crise política no país. Segundo seu relato, a constituição não funciona no seu país. Além disso, ao relatar o desenho, a estudante também referiu sobre a realidade de muitas pessoas que estão sem acesso à moradia, "perdendo suas casas", enquanto outras possuem mais de uma moradia, revelando o contexto de intensa desigualdade social que vive o país. Outros elementos do desenho como o quadro em que está escrita a palavra mulher e outro com a palavra trabalho, também entre círculos entrecortados, representam a realidade de negação de direitos. Conforme explicou a 
estudante venezuelana, os direitos das mulheres não estão sendo respeitados no seu país. Ela destacou a dificuldade de inserção no mercado de trabalho e o contexto de desemprego generalizado. Por fim, a imagem de uma arma, segundo ela, significa que os problemas têm sido resolvidos por meio da violência. Apesar de não ter sido mencionado pela aluna, o desenho da bandeira venezuelana é significativo, pois remete a um símbolo nacional e uma forma de estabelecer um vínculo de identificação com o seu país.

Na próxima imagem, há representação de uma escola, com as figuras do professor e de uma família, que segundo o estudante, estaria levando seus filhos para a aula. Para o estudante, somente haverá justiça no seu país quando o direito à educação, previsto nas leis, for efetivado e transformado em realidade para toda a população. Nesse caso, o desenho remete a uma compreensão deontológica de um modelo ideal da justiça ou da sociedade justa, na sua percepção. Trata-se de uma visão programática do direito e, especificamente do direito à educação, ou seja, mesmo já afirmado nas leis e nos códigos, projeta-se para o futuro como possibilidade e não como garantia.

\section{Imagem 7:}
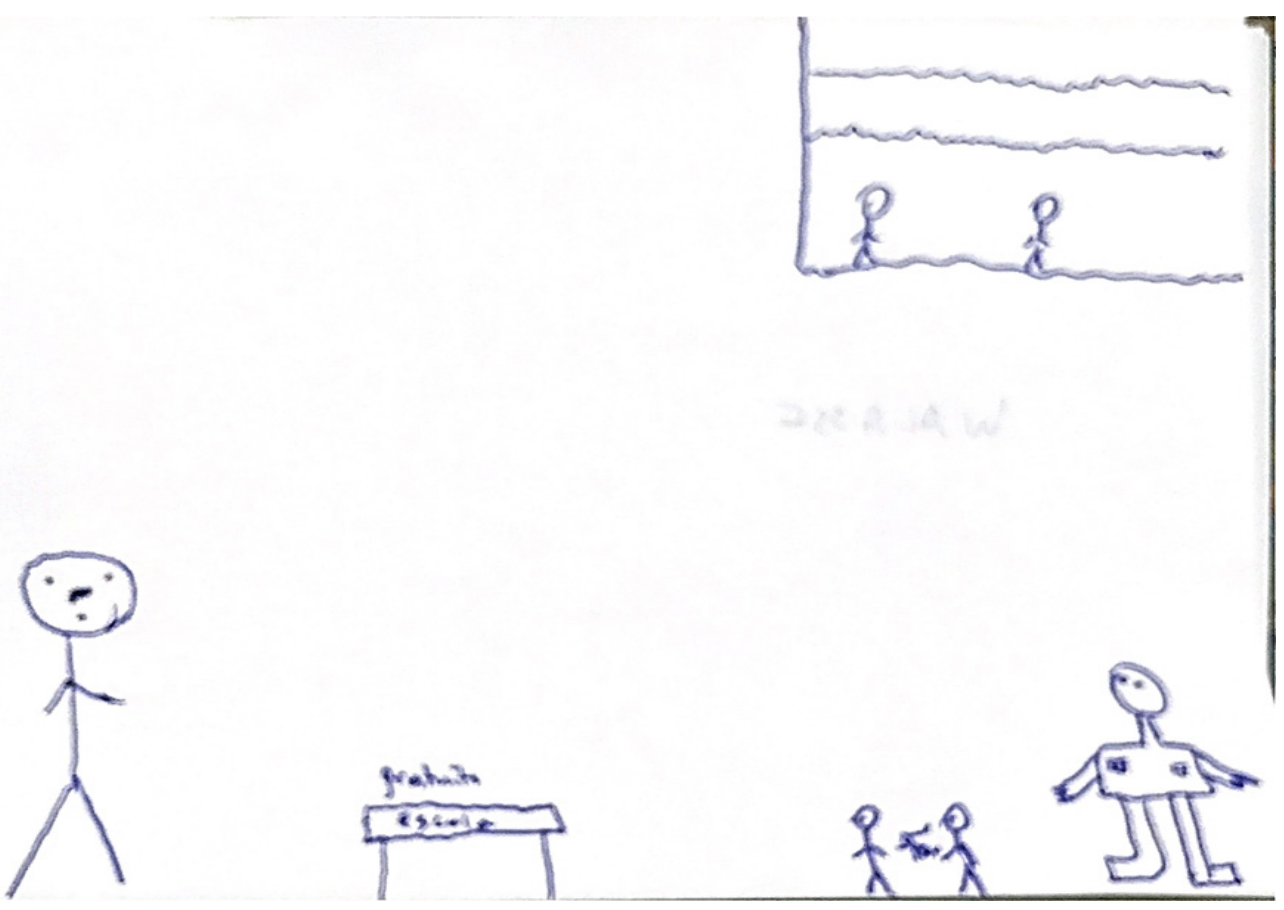

Fonte: as autoras (2020).

\#PraCegoVer: Desenho na cor azul. No centro, uma escola, ao lado esquerdo uma pessoa gigante e ao lado direito uma mulher acompanhando duas crianças no caminho até a escola. No canto superior direito duas crianças em outro caminho. 
O desenho seguinte apresenta quatro elementos diferentes e complementares: uma balança, uma construção com características greco-romanas, folhas ou livros escritos e, por fim, uma pomba carregando um galho na boca. Ao relatar sobre o desenho, segundo a estudante, a justiça tem como inspiração os fóruns romanos e, atualmente, significa um grande conjunto de leis, representado na imagem de páginas escritas. Tanto as dimensões da escrita, presente nos códigos e legislações modernas, como a figura do templo são "fontes visuais indicativas de poder" e "sugerem a expressão da existência de um poder da justiça" (LEITE e DIAS, 2013). Além disso, aparece novamente a reprodução da balança, também um símbolo atrelado ao poder e a disputa entre diferentes pesos e medidas. Nesse sentido, Leite e Dias (2013, p. 14) explicam que, por vezes, a ideia de poder não aparece explícita em elementos imagéticos, apesar de que, com frequência, os desenhos questionam as relações de poder e de força, de punição e recompensa. Além disso, os autores destacam que a balança também indica uma sociedade dual e uma leitura do mundo através das dicotomias entre bem e mal, certo e errado, justo e injusto, igual e desigual (LEITE e DIAS, 2013, p. 14).

Em seu relato, a estudante também destacou o significado da pomba que simboliza a necessidade de ser consolidada a paz, pois, segundo ela, não é possível haver justiça em meio a um cenário de guerras e de conflitos armados.

\section{Imagem 8:}

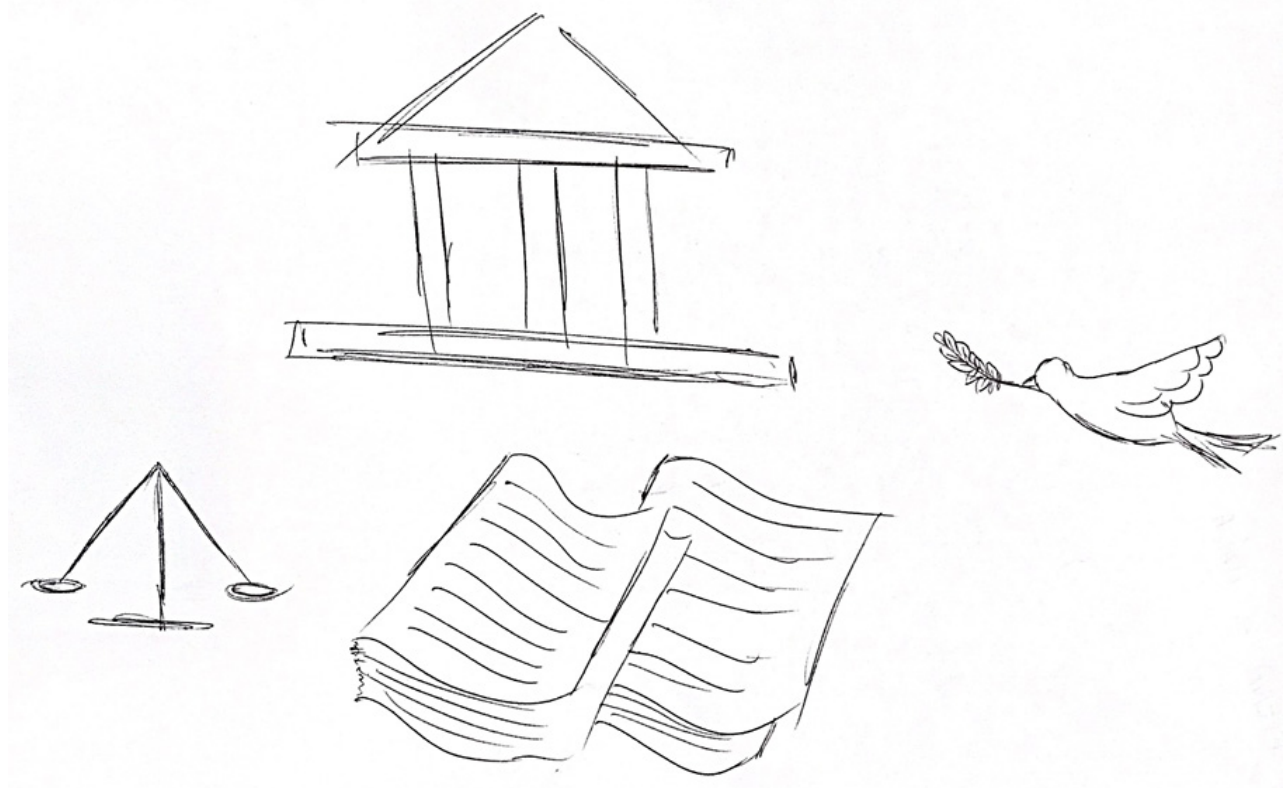

Fonte: as autoras (2020). 
\#PraCegoVer: Desenho na cor preta, quatro imagens ocupam a folha. No centro superior, uma construção no estilo greco-romano com pilares, à direita uma pomba carregando um ramo no bico, no centro inferior um livro aberto e à esquerda uma balança.

$\mathrm{Na}$ imagem seguinte, novamente aparecem simbologias que remetem ao poder, como a figura do tribunal e do juiz, responsáveis pela aplicação das leis e das normas do Estado. No lado direito do desenho, há a presença de algumas pessoas e de cédulas de dinheiro e, conforme, explicou o estudante, a justiça tem como dever julgar tais sujeitos quando usam o dinheiro para fins ilícitos ou em alusão à realidade de corrupção e uso indevido de recursos públicos. Além disso, a figura de uma arma remete às situações de exercício de poder por meio da violência, pois, conforme narrado, a justiça também representa o poder de julgar aqueles que agem por meio da violência.

\section{Imagem 9:}

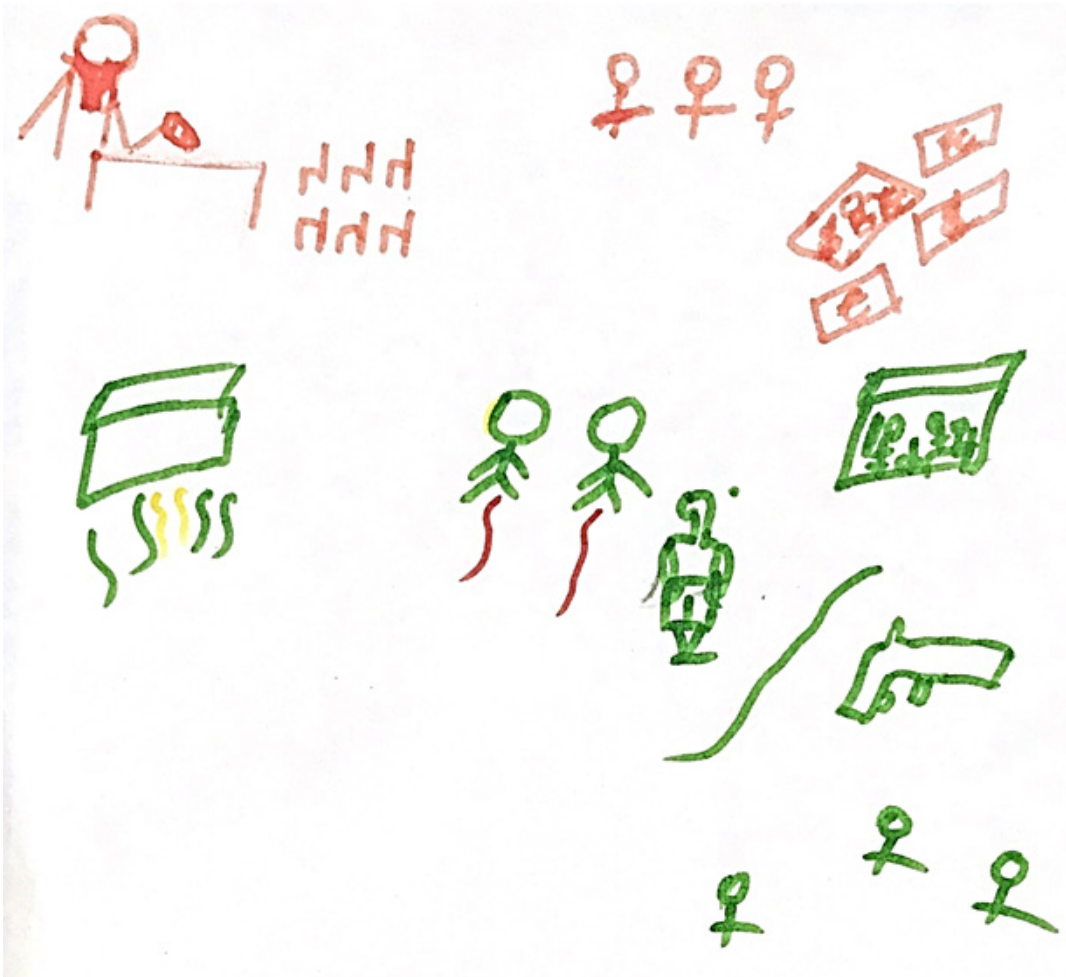

Fonte: as autoras (2020).

\#PraCegoVer: Desenho nas cores laranja e verde. Parte superior à esquerda, na cor laranja, um juiz atrás da mesa, ele segura um malhete, diante da mesa há seis cadeiras. À direita, na cor laranja, três símbolos do sexo feminino (círculo com uma cruz) e várias cédulas de dinheiro. Abaixo, à esquerda, um livro verde com traços verdes e amarelos, ao lado duas pessoas representadas apenas com traços e uma pessoa com mais elementos como camiseta e calção, ao lado uma cédula, uma arma e mais três símbolos do sexo feminino. 
Por fim, no último desenho apresentado, os diversos elementos compõem aspectos sobre o direito e o sistema de justiça, bem como as percepções próprias do estudante sobre seu funcionamento. No lado direito, as figuras foram utilizadas para explicar a organização do sistema que compreende diferentes órgãos, como o Tribunal de Contas e o Tribunal da Justiça, vinculado ao Tribunal de Cassação, hierarquicamente superior, conforme o desenho de um edifício imponente diante das demais. Segundo o estudante, o direito se realiza por meio desse poder e das leis escritas que regulam as relações entre as pessoas, conforme representado na figura de uma página escrita, indicada pela palavra lei, e de duas pessoas vinculadas pelo símbolo das setas. Conforme já apresentado em outros desenhos, também nesse caso aparece a figura da justiça e do direito relacionados à dimensão do poder que se manifesta na lei escrita, nos tribunais e "castelos", em uma ordem pré-determinada que influencia e exerce controle e regulação na vida das pessoas.

\section{Imagem 10:}
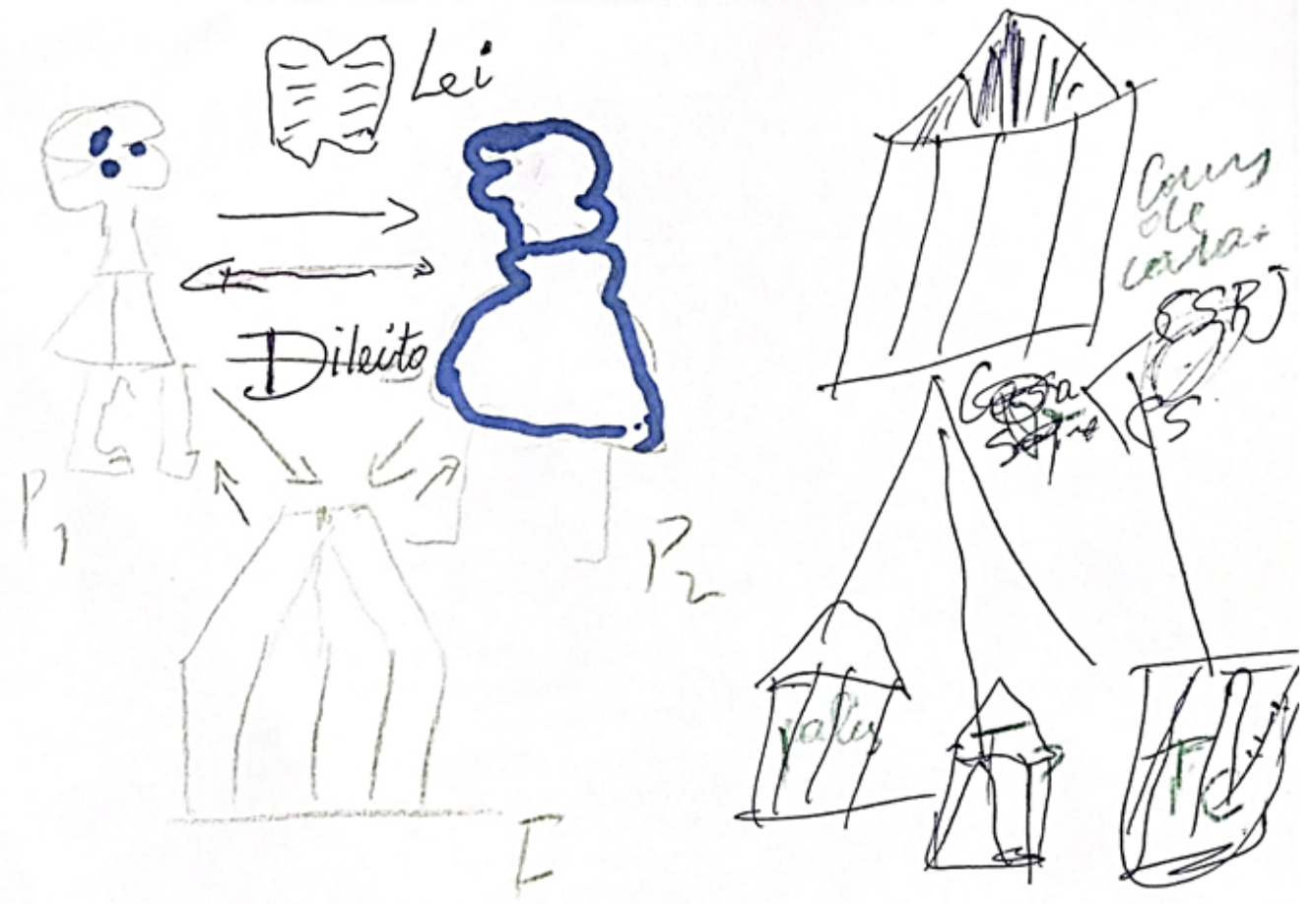

Fonte: as autoras (2020).

\#PraCegoVer: Desenho na cor preta dividido em duas partes. À esquerda um livro aberto e a palavra lei, abaixo duas pessoas com setas e a palavra direito entre elas, várias setas indicando para uma grande construção, um tribunal. À direita o desenho de um tribunal maior e dele saem linhas indicando outros três tribunais menores. 
Apesar de muito diferentes, os 10 desenhos apresentados pelos estudantes evidenciam elementos comuns, como o descontentamento com relação às questões políticas e sociais dos seus países e a associação da justiça e do direito aos símbolos do poder, como a balança, autoridades, lei escrita e edifícios imponentes. Além disso, um dos desenhos apresentou a importância do direito à educação a partir de uma compreensão programática ou ideal da justiça. Ao desenhar e refletir sobre a justiça nos seus países, os estudantes trouxeram também outros elementos da realidade social, política e jurídica, fundamentais ao processo de educação em direitos humanos.

Se, por um lado, praticamente todas essas representações parecem colocar a posição do direito e da justiça como algo externo ao indivíduo, a educação em direitos humanos tem como objetivo a formação do sujeito de direito como corresponsável dos processos políticos e sociais (BRASIL, 2018). Para além de um direito como exercício do poder institucionalizado, trata-se de perceber os direitos humanos como um campo semântico em aberto para ser significado coletivamente a partir da diversidade e da pluralidade de vozes e saberes presentes na sociedade.

Enquanto todos os desenhos demonstram a realidade sobre os sistemas de direito - a negação de direitos básicos, a manutenção das desigualdades sociais, sistemas de justiça inacessíveis e o controle por meio de mecanismos institucionais de poder também apontam para possibilidades de transformação e mudança das relações sociais. Ao contrário de modelos jurídicos que se mantêm longe das demandas da população e da realidade social - como mostram os desenhos - , os estudantes destacam a importância dos direitos humanos, como educação, trabalho e igualdade social para uma sociedade efetivamente justa.

\section{CONSIDERAÇÕES FINAIS}

Apesar de já consolidada a utilização das metodologias visuais em determinadas áreas das ciências sociais e humanas, tais recursos metodológicos ainda não foram muito explorados no âmbito do direito e da educação jurídica. Especialmente em contextos educacionais plurilinguísticos e muito diversos, o uso dos métodos visuais amplia as ferramentas de compreensão e acesso do outro ao incluir dinâmicas com base em desenhos, figuras e imagens. Diante dos desafios da educação em direitos humanos no contexto do ensino para migrantes e refugiados na universidade, o uso do desenho como recurso metodológico permite ao sujeito expressar suas percepções sobre as relações sociais para além da língua falada ou escrita. 
A partir do estudo com a utilização das metodologias visuais com estudantes migrantes da UFPR foi possível refletir sobre as diferentes percepções acerca da temática da justiça e das diferentes realidades sociais e jurídicas em que estão inseridos. Como visto, o desenho da balança retrata uma imagem dual da justiça que, segundo as narrativas dos estudantes, reflete uma realidade de desequilíbrio e desigualdade social. Em vários desenhos, a balança com pesos desproporcionais simboliza uma justiça parcial e uma sociedade de privilégios. No caso dos estudantes haitianos, por exemplo, ficou evidente a relação entre a injustiça, a pobreza e a falta de direitos, enquanto nos relatos dos estudantes venezuelanos, a inefetividade dos sistemas de justiça parece decorrer e problemas institucionais e questões políticas.

Além disso, o desenho de livros em alusão às leis escritas, vestimentas ornamentadas, prédios e grandes construções são elementos associados ao poder e ilustram a imagem de uma justiça encastelada, distante da realidade da população, cuja linguagem muitas vezes é inacessível. Nesse cenário de contradições, o processo de educação em direitos humanos surge como alternativa para formação de sujeitos conscientes dos seus direitos e de transformação social e jurídica.

Por fim, destacamos que o uso dos recursos visuais foi fundamental para criação de um espaço de ensino-aprendizagem sobre os direitos humanos onde todos se envolveram e contribuíram para construção de sentidos e interpretação sobre os temas propostos. Sobre as narrativas dos estudantes, por meio da proposta de desenhar sobre a justiça foi possível acessar um amplo campo de significados e representações sobre o direito, realidade social e política, desigualdades, bem como suas relações diante do contexto migratório. Em síntese, entendemos que utilização das metodologias visuais permitiu reconfigurar a discussão sobre os direitos humanos por meio da valorização das expressões dos estudantes e dos seus repertórios socioculturais.

\section{REFERÊNCIAS BILIOGRÁFICAS}

ACNUR. Global Trends: Forced Displacement in 2019. Disponível em: https://www. unhcr.org/5ee200e37.pdf Acesso em: 06 out. 2020.

BRANDÃO, Ana Carolina de Laurentis. A pesquisa narrativa visual e a formação de professores de línguas. In: MELO-PFEIFER, S.; SIMÕES, A. R. (Org.) Plurilinguismo vivido, plurilinguismo desenhado: estudos sobre a relação dos sujeitos com as línguas. Santarém: Universität Hamburg, Universidade de Aveiro, 2017. 
BRASIL. Plano Nacional de Educação em Direitos Humanos. Disponível em: https://www.gov.br/mdh/pt-br/navegue-por-temas/educacao-em-direitos-humanos/ DIAGRMAOPNEDH.pdf Acesso em: 20 jan. 2021

CANDAU, Vera. Educação em Direitos Humanos: Questões pedagógicas. In: BITTAR, E. C. B. (Org.). Educação e metodologia para os direitos humanos. São Paulo: Quartier Latin, 2008.

CHIK, Alice; MELO-PFEIFER, Sílvia Melo. What does language awareness look like? Visual methodologies in language learning and teaching research (2000-2018). Language Awareness, v. 29, n. 3, p. 336-352, 2020. Disponível em: https://www.tandfonline.com/ doi/abs/10.1080/09658416.2020.1785481 Acesso em: 20 jan. 2021.

CSVM. Relatório Anual da Cátedra Sérgio Vieira de Mello. 2020. Disponível em: https:// www.acnur.org/portugues/wp-content/uploads/2020/11/Relatorio-ANUAL-CSVM2020-V2.pdf Acesso em: 18 jan. 2021.

HAITI. Constitution of Haiti. Disponível em: https://pdba.georgetown.edu/Constitutions/ Haiti/haiti1987.html Acesso em: 05 out. 2020.

COELHO, Mafalda; SIMÕES, Ana Raquel. As imagens das línguas de alunos do $2^{\circ}$ ciclo do ensino básico: foco nas línguas curriculares. In: MELO-PFEIFER, S.; SIMÕES, A. R. (Org.). Plurilinguismo vivido, plurilinguismo desenhado: estudos sobre a relação dos sujeitos com as línguas. Santarém: Universität Hamburg, Universidade de Aveiro, 2017.

LEITE, Maria Cecília Lorea; DIAS, Renato Duro. Imagens da Justiça e educação jurídica na contemporaneidade. XXII Encontro Nacional do CONPEDI, São Paulo, 2013. Disponível em: http://repositorio.furg.br/handle/1/5427 Acesso em: 05 out. 2020.

MELO-PFEIFER, Sílvia; FERREIRA, Teresa. Diz-me lá o que é que tu desenhaste aqui - das narrativas visuais a uma intertextualidade multimodal? In: MELO-PFEIFER, S.; SIMÕES, A. R. (Org.). Plurilinguismo vivido, plurilinguismo desenhado: estudos sobre a relação dos sujeitos com as línguas. Santarém: Universität Hamburg, Universidade de Aveiro, 2017.

MELO-PFEIFER, Sílvia; SIMÕES, Ana Raquel Simões. Introdução. In: MELOPFEIFER, S.; SIMÕES, A. R. (Org.). Plurilinguismo vivido, plurilinguismo desenhado: estudos sobre a relação dos sujeitos com as línguas. Santarém: Universität Hamburg, Universidade de Aveiro, 2017. 
MOORE, Danièle. Prefácio da obra "Plurilinguismo vivido, plurilinguismo desenhado: estudos sobre a relação dos sujeitos com as línguas". In: MELO-PFEIFER, S.; SIMÕES, A. R. (Org.). Plurilinguismo vivido, plurilinguismo desenhado: estudos sobre a relação dos sujeitos com as línguas. Santarém: Universität Hamburg, Universidade de Aveiro, 2017.

RUANO, Bruna Pupatto. Programa Reingresso-UFPR - Aproveitamento de vagas remanescentes para a reinserção acadêmica de migrantes e refugiados: acões de acolhimento. 2019. 432 f. Tese (Doutorado) - Curso de Letras, Universidade Federal do Paraná, Curitiba, 2019. Disponível em: https://acervodigital.ufpr.br/handle/1884/67641 Acesso em: 19 jan. 2021.

RUANO, Bruna Pupatto; LOPES, Sérgio Santos. Programa Reingresso da Universidade Federal do Paraná: avaliação em contexto de migração e refúgio. Em Aberto, v. 32, n. 104, p. 99-101, 2019. Disponível em: http://rbepold.inep.gov.br/index.php/emaberto/article/ view/4224 Acesso em: 30 set. 2020.

SIMÕES, Ana Raquel. Vamos desenhar línguas e a sua aprendizagem? - o desenho como forma de aceder a representações de adolescentes. In: MELO-PFEIFER, S.; SIMÕES, A. R. (Org.). Plurilinguismo vivido, plurilinguismo desenhado: estudos sobre a relação dos sujeitos com as línguas. Santarém: Universität Hamburg, Universidade de Aveiro, 2017.

UFPR. Resolução 13/14. Aprova normas para acesso de migrantes regularmente admitidos no Brasil. 2014. Disponível em: http://www.soc.ufpr.br/portal/wp-content/ uploads/2016/07/resolucao_cepe_09072014-902.pdf Acesso em: 20 jan. 2021.

UFPR. Resolução ${ }^{\circ}$ 63/18. Estabelece e aprova a criação de vagas suplementares destinadas a migrantes em condição de refugiado ou com visto humanitário em todos os cursos de UFPR. 2018. Disponível em: http://www.soc.ufpr.br/portal/wp-content/uploads/2018/11/ cepe-63-18-vagas-suplementares-migrantes.pdf Acesso em: 18 jan. 2021.

UFPR. Cepe aprova iniciativa para aprimorar o acolhimento e a adaptação de migrantes e refugiados. 2019a. Disponível em: https://www.ufpr.br/portalufpr/noticias/cepe-aprovainiciativa-com-objetivo-de-aprimorar-o-acolhimento-e-a-adaptacao-de-estudantesmigrantes-e-refugiados/ Acesso em: 01 set. 2020.

UFPR. Resolução 59/19. Institui o Programa de Formação Suplementar: Ciclo de Acolhimento Acadêmico para Estudantes Refugiados (PFS-Refugiados) destinado aos estudantes admitidos na Universidade Federal do Paraná na condição de refugiados. 2019b. Disponível em: http://www.soc.ufpr.br/portal/wp-content/uploads/2020/02/ cepe5619.pdf Acesso em: 02 set. 2020. 
UFPR. Curso de acolhimento linguístico e acadêmico dá início a ano letivo de migrantes e refugiados. 2020. Disponível em: https:/www.ufpr.br/portalufpr/noticias/curso-deacolhimento-linguistico-e-academico-da-inicio-a-ano-letivo-de-migrantes-e-refugiados/ Acesso em: 02 set. 2020.

Recebido em: 12 out. 2020. Aceito em: 24 jan. 2021. 